\title{
POETRY AS METHOD IN THE HISTORY CLASSROOM: DECOLONISING POSSIBILITIES
}

\author{
DOI: http://dx.doi.org/10.17159/2223-0386/2019/n21a1 \\ Sarah Godsell \\ University of the Witwatersrand \\ Sarah.godsell@wits.ac.za
}

\section{Abstract}

Poetry can present historical material in a non-academic format. This format may be particularly important for students who are excluded from epistemic access (Morrow, 2007). This exclusion stems from many things, but ways of writing, ways of framing history, and whose voices and stories are heard are part of this exclusion. This article explores using poetry as a method of decolonising history teaching, primarily in teacher training classroom contexts. Poetry provides a unique combination of orality, personal perspective, artistic license, and historical storytelling. The form can also draw students into a lesson. As a device somewhat removed from students' ideas about what history is, poetry is an alternative way of investigating ideas of "truth", evidence, narrative, and perspective. It provides an entry point to historical topics, that can be supplemented through other texts and forms of evidence. Poetry also provides a voicing for sensitive topics, acknowledges and embraces complexity and pain. It could also remove the teacher as mediator, even if only for a moment. Additionally, it can open space for marginalised voices and stories. By drawing from local poems, especially by black womxn poets, race and gender are centred in the conversation in a visceral way. International poets open conversations about globally linked histories. Poets from different generations raise questions of continuity and change. All poems are open to examination through historical thinking skills. This article explores the tensions in decolonising the Curriculum Assessment Policy Statement (CAPS) history Further Education and Training (FET)(Senior High School) curriculum and in using a creative medium such as poetry to do so.

Keywords: Decolonisation; History; Teacher education; South Africa; Curriculum; Poetry; Pedagogy; Historical thinking.

\section{Introduction}

In my experience as a lecturer teaching pre-service history teachers in South Africa, there is one question that I have never been able to answer satisfactorily: "History hurts. How can we teach it without causing (or feeling) pain?" This question has been asked of me in multiple ways: 
how not to upset students in the classroom; how not to cause hate; how not let the students leave a classroom feeling unsettled; how not to let the teacher's own feelings dominate or be triggered. This same question, "History hurts", has been dealt with in different ways in literature on history education: some advocate an honesty about present day dynamics (Teeger, 2015) or triangulation of evidence, to try to shift students from their current positions and positionalities to experience and understand different world views (Wineburg, 2001); others advocate historical perspectives specifically to be aware of historical wrongs that have been covered up by distorted or false historical narratives (Dunbar-Ortiz, 2015; Ortiz, 2018; Zinn, 2005). The latter is arguably most imperative for decolonisation (when this involves shifting from a colonial lens and unwriting colonial narratives). This is also most painful, most uncomfortable, and most taxing. Telling honest histories ${ }^{1}$ about the past and present realities of settler-colonial imperialism is painful. How do we teach these histories? How do we equip pre-service teachers to teach history that hurts? How do we do this within a programme of decolonising history content and pedagogy to better teach our students and reflect who they are? This paper explores poetry as a method to decolonise history teaching. I discuss theoretical aspects of using poetry in the classroom, and then illustrate these with examples of poems. ${ }^{2}$ I will first outline the understanding of decolonisation underpinning this paper and then explore the use of poems in the history classroom.

History is an emotionally and politically charged subject, as it is taught and as it is thought about. Education is a similarly charged subject. When we focus on history in schools, we need to be aware of the multiple emotive, pedagogical, and political aspects of history education. By using this as a nexus of how we can explore decolonising and Africanising curricula, we can deal with the legacy of colonial education, how history is being thought of as a possible compulsory subject, ${ }^{3}$ and the implications this would have for history teaching.

1 I am using the phrase "honest histories" here, which is also a contestable phrase. What I mean by this is histories that are evidence based, that are decolonised in that the people writing them are continuously working to undo the colonial lens, who are actively part of re-visioning and uncovering marginalised narratives (that were marginalised because previous histories served specific interests). I use honest rather than as an attempt towards a descriptor that is more specific than decolonised, and not as constrained as ideas such as "triangulated". Rather, as Freire suggests, an "honest" history as one that keeps objectivity and subjectivity in constant dialectical conversation.

2 The poems used in this article are available on www.poetry4historyeducation.com.

3 There is currently a Ministerial Task Team examining the CAPS curriculum, and the possibility that history may be made into a compulsory subject. 
Poetry can be used to bolster the skills that are outlined at the beginning of the CAPS history documents (DoBE, 2011; DoBE, 2011a, 2011b). These skills are not referred to in many of the specific content topics. Poetry can bridge between skills and content, engaging learners into critical thought, writing and historical thinking skills. ${ }^{4}$ This will be examined further below.

This paper engages with some of these questions, utilising specific points on the decolonisation of the curriculum, to help think through various materials we use to teach historical thinking. I also examine the knowledge position they create and then explore the idea of using poetry to counter some of the positionality that western literature on "what is history" or "historical thinking" ends up engendering. I explore what this means for students in a Bachelor of Education course who will be at the coal face of history teaching in the school classroom.

A note on positionality in a paper engaging the concept of decolonisation: I am negotiating my space as a white woman lecturer in an academy that is pushing for transformation. I negotiate this positionality in lecture prep, in classes, in thinking around the discussions we have, and in trying to hold space. White people doing work on decolonisation is complex, and perhaps unavoidably problematic. It is an issue I need to consistently grapple with in this research project. My approach is to make the classroom a negotiated space, with as much discussion lead by the students as possible. I also use my positionality and students' reaction to it to introduce how their own positionalities will impact the classroom. It is an interesting discussion on power dynamics - the various negotiations we have had to allow comfort for discussions about race in class; how that comfort does not translate into a comfort with discussions of gender, class or sexuality; which issues get subsumed into which. These are questions for the larger research project. For this paper, I want to note that my positionality as a white South African woman will have an impact on all I do in class, and what I can do in this paper. I take this into consideration to the best of my ability.

\section{Methodological overview: A high education classroom case study using participant ethnography}

I conducted this study, approved by the Wits Ethics Committee (protocol number H18/10/10), in my Social Science Senior Primary Method 1 and in Third Year Methodology classes in 2018. Full informed consent was given

4 The CAPS document will be addressed more thoroughly below. However, an in-depth exploration of the potential of poetry use in a CAPS lesson is beyond the scope of this paper, and part of forthcoming research. 
to use class discussion and assignments anonymously, unless the student specifically requested their name to be used. The students named in this paper have requested acknowledgment for their poems or ideas. This is according to my ethical clearance. Most work was done in the Third Year Class. There were 47 students in this class, all pre-service teachers in their third or fourth year of study. These students had chosen history as either their major or sub-major, so were committed to thinking through issues around how history should be taught, and were interested in, and conflicted by, ideas around decolonisation. ${ }^{5}$ I did not conduct any interviews, and drew all data referring to this class from our classes in 2018 . We used poetry and discussed decolonisation in this class. This case study is used to support some of the arguments made. I also engage literature on decolonisation, history teaching, and poetry as pedagogy. Methodology is interwoven in all the sections below. The above has given a brief description for clarity purposes.

\section{Decolonisation: On coloniality and/in history, poetry and/in history}

Decolonisation, an exciting impetus for praxis in South African Universities in $2015,{ }^{6}$ has now been used so broadly that it needs a careful definition for it to do any work. I draw from Lugones' thinking on coloniality as the gendered construct of human vs non-human, being versus non-being (Lugones, 2010). ${ }^{7}$ In this paper, I use it to think towards the constitution of the bodies of knowledge we use in relation to the bodies that inhabit our classrooms, pushing into a changing of intellectual canon; the relationship of students, learners, lecturers and authors to knowledge; attitudes towards construction of space-times, as Lewis Gordon proposes "shifting the geography of reason" (Gordon, 2011). In history, it raises the recurring questions "whose histories, whose voices, whose writing, whose knowledge" (Bam et al., 2018, Introduction). Bam references Cabral's call for a "return to the source of indigenous cultural resistance in examining the question of educational transformation" (Bam et al., 2018:17).

Poetry has always been part of this resistance, captured in text from early $20^{\text {th }}$ century by Nontsizi Mgqwetho and SEK Mqhayi (among others) to present day poetry representing issues of racialised, gendered, and sexual

5 While student perceptions of decolonisation are discussed in this paper, these perceptions are explored more fully in a forthcoming paper.

6 I am referring here to the \#FeesMustFall student movement, a movement for free quality decolonised education and insourcing of workers. For more on this see: (Booysen, 2016; Ngcaweni \& Ngcaweni, 2018).

7 It is beyond the scope of this paper to fully explore Lugones' movement towards a decolonial feminism, but I will draw on this thinking in different ways in the paper. 
orientation based oppression (Dominguez, 2012; Mgqwetho, 2007; Mqhayi, 2017). Scholarly work on decolonisation of history, aspects of which are addressed in the recently released book by Bam et al., Whose History Counts, has developed a substantial but fragmented body of work. Bam et al. focus on exploding the idea of "pre-colonial", as well as addressing gaps in the current historiography, through both language and indigenous knowledge systems. The chapters by Mkhize and Tisani are most relevant for this article: Mkhize looks both at African(s) self-framing in historiography and the missing, scattered narratives of black writers. Reframing and defragmenting African history by African writers, whether by retrieving these writings from archives or by applying frameworks of indigenous knowledge practices are discussed by both Mkhize and Tisani as healing. ${ }^{8}$ In this article I looking a concept of epistemological healing, directly addressing narratives of historical wounds. This is relevant for poetry in the classroom, as a current means of reclaiming and presenting knowledge, while re-imagining frameworks. ${ }^{9}$

Looking particularly at the South African academy, the word "decolonisation", if defined, remains useful, as does the literature from which it emerges, even as it is appropriated by a variety of sectors. I approach the idea of decolonisation from a broad dual position of Africanisation and feminist decoloniality. Drawing from decolonial history scholars' NLL Ramoupi and RN Ntongwe's perspective on Africanising the curriculum (using South Africa and Cameroonian education systems as case studies), and the role of decolonisation, ${ }^{10}$ they contend that what is overlooked in:

... pre-colonial African education systems is educational relevance: its close link with social life, both in a material and spiritual sense; its many sided-nesses: and its progressive development in conforming to the successive stages of physical, emotional and mental development of children. In other words, education in African societies had been socially, economically and politically relevant to the society (Ramoupi \& Ntongwe, 2017: 195).

8 Healing is only one aspect of what these chapters raise, and speak to epistemological healing as part of decolonial history.

9 While this book is engaged in this paper, it is beyond the scope of this paper to fully appreciate what it means for pedagogical praxis in history classrooms. I engage the arguments in this book on both writings and values drawn from this book, to strengthen my argument for poetry as historical pedagogy, but a critical aspect of it is decolonising historical timeframes currently used in historiography and in CAPS. To explore using poetry in this is another paper.

10 The work of and impetus for is also laid out in the report of the Ministerial Task Team that investigated making history into a compulsory subject (Ndlovu et al., 2018). I would argue more strongly for the decolonisation of the CAPS curriculum, which would entail, but I believe be broader than, its Africanisation. 
It is especially this "many-sidedness" to education, that is concerned with emotional, spiritual as well as mental development, that I argue towards in this article. History must locate itself emotionally, with students and learners, as well as mentally, and cognitively. That is to say, with Lugones, that history must resist coloniality, and its thoughts and dichotomies of being and non-being. (Lugones, 2010) However, the history curriculum in South Africa is global, I argue for connections with decolonisation and the Global South- aspects of which could fall within a broad diasporic use of Africanisation. The crucial elements for me about decolonisation are examining what historical gaze we are working with, what this does to knowledge production, where and how the students/learners locate themselves in that, and then, particularly, the feelings that this historical gaze and knowledge production evoke in the students/learners, taking into account the positionality of the learners.

Ramoupi and Ntongwe further call for a "re-appropriation of the production and dissemination of knowledge in universities in Africa. Detached from the present coloniality geo-political configuration of the world" (Ramoupi \& Ntongwe, 2017:196). In this, I see a reconfiguration of power structures as we think about knowledge production, theories of historical thinking, and methods used in history classrooms. In this paper I draw on an understanding of Africanisation of the syllabus as shifting the point of knowledge production, the knowledge lens, and power centre, rather than knowledge specifically coming from the spatial unit of "Africa". Another aspect of decolonial theory I use in this paper, I draw from Nkenkana's framework, decolonising gender. She explains that:

... decolonizing gender places the scholar in the midst of people in a historical, peopled, subjective/intersubjective understanding of the oppressing-resisting relation at the intersection of complex systems of oppression. To a significant extent, it has to be in accord with the subjectivities and intersubjectivities that construct and in part are constructed by the situation (Nkenkana, 2015:41).

For Nkenkana, decolonising gender is a way to access a nexus of powerrelations as they play out within the person, within the text, within the history. Babalwa Magowana pushes this further, engaging moving beyond the gendered and binary nature of institutions of learning, working to remove the patriarchal bias. (Bam et al., 2018:77) This applies to every level at which I think through a decolonisation process of knowledge and pedagogy: in the teacher education space, in the curriculum, and in the 
school classroom. It allows for multiple processes of examining knowledge production and co-production, as well as examining interactions with knowledge produced. Nkenkana urges that the "women's liberation struggle should not be reduced to efforts of incorporation of women within the patriarchal, colonial and imperial modern system/s women seek to reject" (Nkenkana, 2015:41). She makes the point that decolonising gender produces a different kind of knowledge, and (as she is used by (Wills, 2016) when specifically considering the South African history curriculum) that decolonisation of history without a gender-lens will produce a history that excludes the type of knowledge, resistances, and realities, produced and used by women. Decolonisation, both of content and pedagogy, must produce a different kind of knowledge: knowledge with a different centre, with different gravitational pulls. I argue that poetry is a useful tool towards this goal.

Using poetry can enable a historical pedagogy that takes into consideration the relational and shifting positionalities of the students, that disrupt ideas of historical objectivity trapped in Enlightenment logic (Olaowula, 2016). Poetry, seen as a creative medium rather than an "objective" source, allows students to question the gaze we use in history in teacher education, in history in the high school classroom, and in the CAPS history curricula, Poetry provides different lenses onto gender, race, queerness and marginalised voices. I argue for the potential of poetry use in history classrooms as a decolonising pedagogy, as a writing/thinking/recording mechanism that can be used as a resistance to coloniality in whose voices and subjectivities it lives in, and how it is brought into the classroom. "They chart new ways in which meaning might be further harnessed by placing the creative and the explicitly critical alongside one another" (Gqola, 2011:1).

I also argue for poetry as a method for facilitating humanising pedagogy, (Freire, 1996), both in whose voices it accesses, and how it can function with voice(s) in class. Mkhize, in Bam et al., argues that South African history is an archive of white voices writing about Africans, and what is missing is the voices of Africans speaking in their own idiom, in their own framing, writing their own present and history. This presents scope for further study, for example examining the poetry of Mgqwetho and Mqhayi, among others. History is also accessed in and through poetry, as poetry is written in a historical moment, viewed in a historical moment, and accesses historical moments. Gqola writes, "History is referenced, questioned, revisited and its archives are read for their granularity" (Gqola, 
2011:1). Therefore, poetry is voice, poetry is historical evidence, poetry is historical archive, poetry is an opening into different paradigms, and framings, in which Africans are not belittled, but are writing, framing, and nuancing their own stories.

\section{Decolonisation in context: Thoughts with and through a History Methodology classroom}

What does decolonisation mean, in the context of history and history teaching? What histories do we teach? "Whose history counts?" (Bam et al., 2018). This goes beyond whose voice is heard. It is about whose framing, whose narrative, whose language, whose terminology, whose world view and definitions of reality and humanity are used in the curriculum and in the classroom. These vectors are slippery to pin down. I asked the Third Year History Methodology class for their definitions of decolonisation. ${ }^{11}$ Their answers ranged from moving away from a European enlightenment model of humanism, to a co-creation of knowledge (between learner, teachers, and historians), to Africa centred knowledge, to knowledge that centred around untold and marginalised stories. The interpretation of decolonisation that held the most purchase with the students and around which we had the most robust discussions, came from a student Moosa Khumalo, who expressed his vision of decolonised history as "a history in which I can see myself, and I am not belittled". ${ }^{12}$ Khumalo explained how so much of what he sees being referred to as decolonised history focuses on injustices committed to indigenous, marginalised, or brown people. ${ }^{13}$ He envisioned a decolonised history that goes beyond this. Which again broadened the way in which we were able to conceptualise decolonising the curriculum: including historical narratives which shift ideas of "civilisation", "development" or "progress" away from the Global North. These aspects are in the curriculum (the Ancient African civilisations of Mali, Ghana and Songhai for example) but much more can be done to develop them (Bam et al., 2018; Ndlovu et al., 2018). The starting point of "a history in which I am not belittled" is a complex, phenomenological and nuanced understanding of $\mathrm{I}$, and an understanding of how the "I's" relate

11 This is part of a larger research project on the decolonisation of history teaching at Wits School of Education. Ethical clearance has been obtained for this research. While the standard procedure is to retain confidentiality and not reveal students' names or identities, as some students are either poets or want to pursue careers in academia, they have requested that they be named in their article, and so associated with the ideas they came up with. This is in accordance with my ethical clearance.

12 Cited with permission, as part of a project on Decolonising History, reviewed by Wits Ethics protocol number $\mathrm{H} 18 / 10 / 10$.

13 By "brown" Khumalo is referring generally to people of colour. 
into different, fluid and shifting "we's", that interact with knowledge and power, past and present, in different ways. ${ }^{14}$

The idea of "a history in which I am not belittled" at a seminar presentation of an early version of this paper, elicited the question "is it possible to decolonise history? Is it possible to decolonise a history of colonialism, for example? Is that project not antithetical?"15

Often, historical narratives are about powers enforcing themselves on others, of marginalisation, of dispossession, and even these tell stories that map the power narratives of the present world (Trouillot, 1997). However, Rebecca Solnit argues in Against the Dark, histories of hope, resistance, and victories exist, but need to be unearthed and collected (Solnit, 2005). Solnit writes of histories of resistance and victory in political terms, mainly about the United States. But those histories exist in an Africanised history as well. So, histories of pain need to share historical space with histories of power, beyond the current narrative of victory against apartheid. To expand Khumalo's premise, a decolonised history would also be history which does not impose specific knowledge boundaries or values on types of text, on written or spoken word, and which can allow the necessary analytic critical thinking skills to flow from and through different kinds of writing. This allows for histories told through different lenses, rather than a western-centre perspective, even if it is focusing on the atrocities committed against, as Khumalo phrases it "Brown people". Nelson Maldonado-Torres speaks to this in his article ten theses on decoloniality, and also used poetry in an implicit response to student "breathlessness"16, in a long trajectory of merging poetry and academia, to express what is beyond the bounds of academic writing. (Maldonado-Torres, 2016).

\section{How can poetry enhance skills laid out for history learners in the CAPS curriculum?}

Poetry can be used to bolster the skills that are outlined at the beginning of the CAPS document. Poetry can bridge between skills and content, engaging learners into critical thought, writing and historical thinking

14 These ideas, of how we think of African history, especially precolonial history, are explored in depth in the publication "Whose History Counts: Decolonising African Pre-colonial Historiography"(Bam et al., 2018). As this paper focuses on method, in the teacher education classroom, it is important for me to centre students' thinking around the subject

15 This was asked at a presentation at the Centre for Humanities Research, at the University of the Western Cape, where a version of this paper was presented on the $8^{\text {th }}$ of May 2018.

16 Maldonado Torres explores this breathlessness as a type of voicelessness, tied to the classist and racialised way in which students are unvoiced in liberal university spaces. 
skills. Poetry used as a tool is better suited to enhance some skills than others. Here I will examine what poetry can do in relation to the skills set out in CAPS. The CAPS document begins by outlining that "history is a process of enquiry" (DoBE, 2011:10). Poetry is one of many of pieces of evidence that can be used to answer and evaluate the enquiry. Poetry does have unique attributes that make it useful.

Lindsay Wills has written convincingly about decolonising the CAPS curriculum in terms of gender (Wills, 2016). She stresses that decolonisation needs to entail shifting the gaze, rather than "adding in women". In "Tongues of Our Mothers" Xaba successfully shifts the gaze, and in one poem, provides a trajectory of gendered history for students to explore and unpack (Xaba, 2008). It is again the way this information is presented (Shalem et al., 2013) that brings students into proximity with the knowing in an accessible way, opening room for historical thinking and analyses.

Poetry becomes particularly useful for two skills described in CAPS as being able to: "recognise that there is often more than one historical perspective" and "explain why there are different historical interpretations" (DoBE, 2011:10).

As unapologetically artistic expression from one person, poetry presents a unique perspective, yet it can be engaged and unpacked through historical thinking skills. Poetry can also present a non-dominant narrative which is important for understanding multiple narratives. In my teaching, I have also used music videos for these purposes, particularly Simphiwe Dana (Bantu Biko Street), Beyonce (Formation), and Jay-Z (story of OJ) as well as music like Thandiswa Mazwai (Nizalwa Ngobani) and Akala (Maangamizi), and other kinds of performance art like S'thembile Msezane's work. The performance art of S'thembile Msezane, particularly the work she performed while the statue of Cecil John Rhodes was being removed, encouraged the students to "participate in constructive and focused debate through the careful evaluation of historical evidence" (DoBE, 2011:10), as we supported and corroborated with other types of historical evidence. There is need for further research here about what kinds of art forms resonate with students, and how they can be used as tools of engagement as well as forms of evidence in history lessons, although this is beyond the school of this paper.

Wills explored the potential, and limits, of the current history curriculum (Wills, 2016:22). She argues that the curriculum poses absolute limits for 
"gendering decolonisation". While her argument is specific to gender, I use "gendering decolonisation" as a heuristic device to question other power structures in history that open potential for, or pose limits to, decolonisation. Wills argues that "Decolonising gender in the history curriculum, therefore, means no longer accepting that accounts of the past which either gloss over or obscure women's experiences - especially Black women's experiences - are "true" "objective" and "universal" (Wills, 2016:24). She argues, using scholars ranging from Nkenkana (2015) to Spelman (1989), Spivak (1988), and hooks (1981), the need to decentre the (white) male as the normative gaze through which history is seen. This is a continuous project in the exploration of history. However, Wills uses this moment to offer decolonisation as a lens through which to examine which gazes are implicit in the CAPS history curriculum. This is the lens which I want to use to push the thought further into the tertiary teacher education space, with intention to enable students to decolonise in South African school classrooms.

There is also an urgency to decolonise theories of historical thinking and history pedagogy. These have often emerged from western orientations, and so positions of privilege. While we work with these theories to empower our students, the potential of the history classroom is often left open to the individual history teacher - it can come alive only in sepia tones, populated by distant figures, timelines, names, and birth and death dates. Or it can come alive in colour, connected to each individual and collective in the class, where every historical breath is connected to the breath we take in each class. Wills argues that:

... the theoretical challenges posed by women's and gender history to the discipline's very foundations involves, in no small way, getting to grips with the politics of the production of knowledge. History curricula are particularly potent sites for the construction and diffusion of knowledge and interpretations of how the past relates to the present. As such, national history curricula can be seen as extensions and vehicles of wider ideological and socio-cultural (in) balances of power and thus often sites of political socialisation (Wills, 2016:23).

\section{Putting the poetry into history teaching as decolonial praxis}

This is the history we didn't learn:

From 1952 to1960, the people of Kenya mounted a fierce guerrilla struggle, the Mau Mau uprising, to reclaim their land 
and freedom from the British. The British incarcerated, tortured, and murdered approximately 25,000 Kenyans. Men, women, and children. More than a million Kenyans were detained for over eight years in concentration camps- barbed wire villages where forced labour, starvation, and death were routine.

This is the history we read in school.

President Jomo Kenyatta's speech, ten months after Kenya's independence:

Let this be the day on which all of us commit ourselves to erase from our minds all the hatreds and the difficulties of those years which now belong to history. Let us agree that we shall never refer to the past. Let us instead unite, in all our utterances and activities, in concernfor the reconstruction of our country and the vitality of Kenya's future (Excerpt from the poem "History Lesson" Patel, 2010).

Poetry has gained much popularity in South Africa over the last few years. Collective Amnesia, a ground breaking debut poetry collection by Koleka Putuma, is going into its $8^{\text {th }}$ print run, previously unheard of in South Africa (Putuma, 2017). Her work has been added to curricula in South Africa and abroad, indicating an academic, as well as popular, recognition of the work's importance. And this is not an isolated incident. Putuma has broken many glass ceilings and a space is opening for young poets to have conversations about themselves and the world they find themselves in. These new poets deal with a multiplicity of themes. Some, as the title of Putuma's collection "Collective Amnesia" suggests, deal explicitly with the histories of South Africa and Africa, particularly those silenced histories that are so manifestly visible in our present socio-political climate. Others deal with history and present of spirit, genealogies of daughter, mother, grandmother, histories of language, realities of a multiplicity of everyday lived experiences. Poetry has also expanded in academic spaces: the ZAPP (South African Poetry Project), led by Professor Denise Newfield, looks specifically at poetry in school classrooms, as well as understanding poetry as Indigenous Knowledge Systems. What does this mean for history teaching? And decolonisation?

The challenges referred to above by Wills are visible and tangible in Patel's poem History Lesson. The righteous indignation of the 9-year-olds, scribbling "Purkiss" pigface" in their books powerfully countermanded by the emptiness implied by Kenyatta's invocation of forgetting, and the political purpose of those two positions shown by the "history we weren't taught". However, Patel's poem is not just applicable to gendered 
decolonisation processes. It is important to go back to the potentiality of decolonisation and invoke the scope of feminist interrogation of foundations of knowledge production and power.

One of the theories that I bring to my classes during the process of thinking through decolonisation is Crenshaw's Intersectionality (Crenshaw, 1990). While there are debates around this concept, and its deployment especially when focused solely around identity rather than vectors of power and oppression, the theory proves very useful in class in introducing students to the multiple and intersecting sites of power and oppression that class, race, gender, sexual orientation, ability, and other embodiments bring about. This allows them to situate themselves in the present and in the histories, we are encountering, in sites and intersections of privilege or oppression. Drawing out Wills' argument pushes the intersection between race and gender. This could further be expanded to include intersections of class, of political ideology, and multiple other power assemblages which people battle or inhabit at different points in time.

Wills argues that "radical re-imagining is required to account for multiple standpoints and perspectives, without which one hegemonic version of events is simply replaced by another" (Wills, 2016:23). I argue that this radical imagining needs to be pushed in pedagogy as well as in content, as this radical re-imagining must be expanded into politically gendered, raced, classed, queered, structures. Poetry is always a visioning and re-imagining. Carefully chosen poems (see below) can bridge this re-imagining into the history classroom, as a bridge over which students are able to walk.

I use the term radical in its invocation of return to roots, thinking through Freirean pedagogy (as used and interpreted by hooks), as well as examining more contemporary explorations into decolonisation, Africanisation, or other unpackings and re-orientations of historical thinking and teaching. This idea can also be linked back to the urgency of decolonising theories of historical thinking to allow student teachers, and history students, to make sense of and hold the complexity of emotions that emerge in history classes of the Global South.

Another definition I work with in this paper is a decolonised history as history where the knowledge (and knowledge production) is not removed from those studying it. This references a Freirean, but also radical feminist approach, where knowledge is understood as praxis (knowledge and reflection on the knowledges impact on one's own life) (Freire, 1996; 
hooks, 1994). The knowledge in the CAPS curriculum remains Eurocentric, or at least lacks a serious focus on African history, as the Ministerial Task Team investigating the implementation of history as a compulsory subject noted (Ndlovu et al., 2018). Howard Zinn suggests actively remediating historical narratives that have normalised colonialism (Zinn, 2005). This needs to be done in many spaces, on many levels: through curriculum and pedagogical reform, through academic and popular historical writing, through what kind of sources are used and heard in classrooms. It needs to become part of how we educate students learning how to teach history. I show below how poetry offers a productive way of positioning knowledge in relationship to students.

\section{How poetry can be used to decolonise history lessons}

Poetry creates a world and invites people to find themselves in that world. That world is layered and carefully constructed. Layers of history and lived reality and layers of careful image and symbolism can be linked by carefully constructed thought. But, when posed as an exam question, students argued that poetry cannot be used in history because it is "too emotional". ${ }^{17}$ This presents the idea that history is factual, evidenced, rational, and not emotional. Of course, history needs to be factually argued, with evidence. However, students (as well as teachers, and even, the Ministerial Task Team suggest, the CAPS curriculum) tends to steer away from "history that hurts", or history that provokes emotion in class (Ndlovu et al., 2018).

It is precisely this rationalised, fact-based, unilinear history from which students seem to feel removed. Olaowula argues that this kind of history, tied to ideas of rationality embedded in Enlightenment ideals, strips history of its emotion and so removes an active element of history. (Olaowula, 2016) When this history is taught well, it offers multi-perspectivity and insights on historical narrative. But when taught as "knowing history" as opposed to "doing history" (Tambyah, 2017) it offers little entry point for students to find and position themselves, so little possibility for decolonisation. bell hooks argues for a vulnerability in classes, of both the teachers and the students (hooks, 1994). This kind of vulnerability requires a rigour of reading as well as a rigour of understanding historical narrative and positionality. It requires both students' and teachers' voices and critical

17 Student responses in a history methodology exam, Educ2206, June 2018, Wits School of Education. 
understanding. ${ }^{18}$ This also speaks to Nomathamsanqa Tisani's work, in (Bam et al., 2018:15-31) that works towards debunking current historical periodisation, but more crucially, drawing on the process of ukuhlambulula, to cleanse and heal bodies of knowledge and knowledge creation from the colonial malady. Poetry is one entry point into this, with its historical base in oral tradition in many African societies, and its current use as a space of expression and healing (Gqola, 2011; Hlalethwa, n.d.; Kim, 2013; "Koleka Putuma," 2017). Tisani makes the call for a re-imagining, a need to create new frames and narratives for understanding. The same can be said of the CAPS history curriculum, as highlighted by the MTT (Ndlovu et al., 2018). Poetry is in part an exposition and simultaneously an answer to this. Gqola writes: "few sites demonstrate the inadequacy of existing critical vocabulary as spectacularly as contemporary women's poetry" (Gqola, 2011:5). So how can poetry specifically be used in the history classroom, both in Teacher Education and in High school?

Poetry is not in itself either decolonial or historical. Or new. Poetry has been used to challenge colonisation, in printed form, for at least a century (Mgqwetho, 2007; Mqhayi, 2017). ${ }^{19}$ The current wave of popularity of poetry can be useful in Teacher Education programmes, as well as in school classrooms, if combined with rigorous historical critical enquiry. Poetry provides a semiotics that is not necessarily academic or historical, but that can be accessible and is currently popular. It deals with both history and present, emotion and thought. I show, using excerpts from several poems, that well-chosen poetry can support the CAPS curriculum in both content, and skills development. I will expand on this with some specific examples of both content and skills.

There are several ways that poetry can be used to teach history, each of these ways involving different skill sets. Poetry can be used to get students to do their own writing and engage with their own history. This happened in my First- Year methodology class, where I opened with a poem, I expect more from you by Vangile Gantsho.

18 Voice is a contested concept. Gennrich and Dison work with the "use of the metaphor of 'voice' for enabling agency and asserting identity" and I work with this definition (Gennrich \& Dison, 2018, p. 2).

19 The poetry of Mqhayi and Mgqwetho is an important example of poetry as anti-colonial form. See Mqhayi's poem On the Sinking of the SS Mendi as an example. Poetry, in different forms, has long been a form of anti-colonial resistance, but the in-depth exploration of such is beyond the scope of this paper. The specific potential of poetry as a decolonial pedagogical tool in terms of language and evidence is explored in a forthcoming publication. 


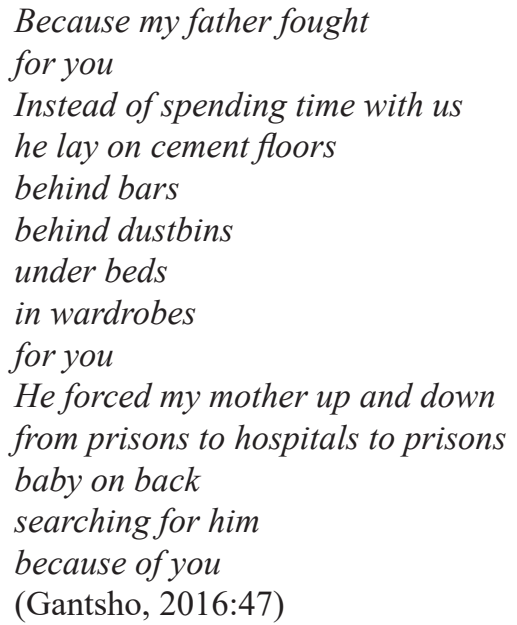

In this poem the poet engages with the realities of her family growing up as part of the ANC's struggle against apartheid, and her pain and anger at what she perceives as an ANC failure in post-apartheid South Africa. It is a deeply personal poem. It also engages gender in the liberation struggle, the states of emergency in the 1980s, ANC in exile, and ex MK veterans in post-apartheid South Africa. It contains a historical argument: that the ANC has betrayed the everyday people who worked and sacrificed for it.

I used the poem to introduce the "Big Six" historical thinking concepts, as originally outlined by Peter Seixas: cause and consequence, continuity and change, working with evidence, historical perspectives, ethical thinking, and historical significance (Morton \& Seixas, 2012). Now, contestability has been added (Tambyah, 2017). The students initially engaged with and were moved by the poem. But they saw it as a text, a piece of emotion that had been voiced. In examining it through historical thinking skills, the poem came alive in other ways, and became a space of co-creation of knowledge.

In the poem History Lesson by Shailja Patel, Patel actively brings marginalised voices into the power structure of the history lesson (Patel, 2010). The poem interweaves the moral lessons taught in history classes to children of 9 years old, with history that was actively silenced, the numbers of Kenyans who died before liberation, and the horrifically brutal treatment of women in camps .She brings in Kenyatta's speech, that she took decades to learn by heart, but was never taught in class. Interestingly, for use in teacher-education classrooms, the reference to the peaceful multi-racial nation gives the poem a particular resonance in South Africa. 
Patel's poem is raising powerful questions of decolonisation in three ways: first - she deals with African history. Secondly, she explicitly makes the poem about what was taught (and learnt), and what was not. This frames the power that this history classroom, and the history narrative chosen for that classroom, have. Thirdly, she presents historical facts starkly, as if she were teaching them. There is no poetic language, there are no poetic devices used in the last stanza of the poem. She presents a historical narrative that is not silencing colonial murder, rape, and theft. ${ }^{20}$ This poem contains a historical argument about what history is silenced and also engages ethical thinking and multi-perspectivity.

In another lecture, I brought both poem and poet into the class. Mjele Msimang performed As Long As in the Third Year Methodology class. This poem also takes an explicitly historic ${ }^{21}$ approach but unfolds history in a different way. Msimang uses poetic devices more explicitly - making the images both more and less visceral than Patel. He invokes history-inpresent, using the concept of a "born free" $"$ ? while gesturing to the global history-in-present structures that maintain global (and local) inequality. He speaks on an economic, political and spiritual level - mentioning both the United Nations Security Council and the unnamed bones of the South African colonial era:

... as long as the mass graves scatter along the hills, under city walks, bones unable to decompose for they have not been named $i$ was never born free

In this he shows how an idea of a decolonised history, maintaining an African perspective, can be global. He raises students' awareness of their place in space and time, and power structures and injustices, without specifically referring to history. The emotions of the poem take intellectual input, and political and historical awareness and knowledge - and thus could provide interesting frameworks for several historical content lessons.

Having the poet in the class brought an immediacy of the voice and the history into a space where the students could see and touch the source of the poem, and the source of the information. As Msimang is a young

20 As this is introduced in class, I am careful to use trigger warnings, and to discuss the limitations of such warnings. I am aware of myself as white teacher, myself as a woman, myself as person deciding which histories are in this classroom and which are not. I am aware of the openings made by the poem, and the way it draws one line through the single history presented and maps out a complicated maze with the "histories we didn't learn". These are the kind of complexities I hope to engender in my students.

21 Someone in South Africa who was born after the first democratic elections in 1994, and so post-apartheid. 
black South African, students can see aspects of themselves in him, which bring them closer to the knowledge and the history, even though the history Msimang invokes is broad and global, tying in with themes of emancipatory internationalism perhaps not immediately familiar to the students.

\section{Poetry from the classroom: My history, my identity, my point of view, my voice}

Writing as a methodology to enhance critical thinking is widely lauded (Bean, 2011; Elbow, 2000; Gennrich \& Dison, 2018). I suggest that creative writing and poetry can offer a space for students to explore their own position in the world, their thoughts and opinions on this position, as well as the complexities of historical cause and effect, continuity and change, and ethical thinking. Kelly argues that poetics (although in their case using hip-hop) can help reduce alienation of students from the texts they are learning (Kelly, 2013). I argue that beyond this, poetry can bridge political and social space-time, towards integrating the students into their own historical narratives and voice. I offer two examples:

After introducing particular historical concepts in class, I asked the students to write their thoughts after the lesson, without specifying the form in which they should write. In the next class one student brought a poem he called The Reckoning urging Muslim South Africans to engage with their positionality and be honest about their position in society in post-apartheid South Africa. This poem contains a historical argument and historical evidence (the student used specific statistics, indicating economic status of different racial groups). This is a complex linking of positionality, ethical perspectives, cause and effect, continuity and change, and historical perspectives.

Another poem was written by a fourth- year student Dipela Jackie Mondi, who is a published poet. She was not versed in poetry as history-teaching method, but her experience in poetry allowed her to integrate her poetry into our conversations on historical thinking concepts. Her poem is called We Need New Plumbers and is dedicated to Michael Komape and Lumka Mthethwa - both five-year-old children who drowned in pit latrines in their schools, in 2014 and 2018 respectively. In class we had spoken about legacies of colonialism and apartheid in South Africa: Mondi brought up was Bantustans, and poor infrastructure in rural areas in designated Bantustans. As a future teacher, she is emotionally invested in school infrastructure, which brought her to these tragic deaths in under-resourced 
schools. Her poem starts:

We need new plumbers

In place of current plunderers

Whose stomachs are bottomless pits

That left us with pit latrines

Speaking about her poem, Mondi explicitly connected past with present: the apartheid regime created the pit latrines, the lack of change has left us with them. When a poem written by a student is used in class it opens historical thought and discussion. With this particular poem, because of the political nature of its content, it opened space for debate. Because content is student generated it also disrupts the power hierarchy in a Freirean/ hooksian way. This can, in turn, be used in the high school classrooms in which the students will teach.

These poems arose spontaneously. I did not prompt or ask for poetry, because there are complications around this as a task: it is not a form with which all students are comfortable. While I think it $\mathrm{ca}_{\ldots .}^{22}$ open more opportunities than it closes (it can facilitate students doing historical writing and thinking in their mother-tongue, for example) more research is needed before introducing writing poetry as a method.? ${ }^{<>}$However, the fact that these poems (and others not discussed in this article) arose spontaneously suggests a positive reaction to poetry as method and poetry as conversation.

I have discussed two ways poetry can be used in the classroom: poems already written can be used to convey argument and content, different historical perspectives, and often to highlight marginalised historical voices and narratives, or poems can be used as writing exercises to understand voice and agency, as well as evidence, in creating historical argument.

In the first scenario the poems need to be used as resources along with other materials and teaching strategies. All historical thinking skills need to be utilised in analysing a poem: contextualisation, corroboration, close reading, sourcing. Doing these things with poetry may provide the added benefit of getting students to question artistic pieces as they do academic pieces, to apply the same rigour of critical thinking to YouTube videos, as they do (or should) with articles found online.

In the second scenario, students are required to be vulnerable about themselves and their lives or open their perspectives on the world. In

22 This forms part of a larger interdisciplinary research project around decolonisation. 
both scenarios they are required to engage with historical themes in their own lives, linking to history, to current affairs, or elements discussed in the classroom. This enhances writing skills, historical thinking skills, and, if the poem is examined in class, skills such as corroboration and contextualisation. This shifts the historical framing to the students themselves, and then, as a class, we can look at that framing and make sense of it.

\section{Towards a framework for using poetry in history lessons}

Not all poems will work effectively to decolonise or teach history. In this section I set out some criteria for a poem to be useful in a history lesson, before engaging the ways in which poetry can provide entry points into history, hooks into narratives, and spaces for students to explore their own historical voices, their own histories. This is summarised in Table 1.

Poetry can be examined like any other piece of evidence, using the historical skills of close-reading, sourcing, and corroboration, to understand the complexity and the histories in the argument. While the poems serve this objective historical function, they also serve to connect the present with the past and connect the students with the histories they are studying. Teeger has argued for the necessity of this in post-apartheid South Africa, as well as the difficulty of achieving this in history classrooms in high schools (Teeger, 2015).

The poems I have discussed make use of historical arguments, collected through the poets' own research and historical evidence (Bam et al., 2018; Monte-Sano, 2012; Morton \& Seixas, 2012; Wineburg, 2001). This is crucial for a poem to function in a history lesson, especially in the CAPS curriculum where teachers are fighting against time to cover the required content knowledge.

The poem must engage at least one historical thinking concept. This is not a difficult requirement to fulfil, as, if nothing else, the poem engages a perspective. However, this perspective needs to engage historical content, or present content that the teacher or the students connect to historical content. The poem must be compelling. It must present information in a way that opens new dimensions to learners or allows them to see something in a different way. This is particularly why I argue for poetry to teach history right now, where poetry is increasingly a popular youth activity, spoken word often vying with popular music to convey societal messages. 


\section{Tabel 1: Guidelines for using poetry in History classrooms}

\begin{tabular}{|c|c|c|}
\hline Criteria & How to identify & $\begin{array}{l}\text { Linking to CAPS } \\
\text { content \& skills }\end{array}$ \\
\hline $\begin{array}{l}\text { Connect with historical } \\
\text { arguments }\end{array}$ & $\begin{array}{l}\text { The poet implicitly or } \\
\text { explicitly makes reference to } \\
\text { historical events, or current } \\
\text { events with historical tracing. } \\
\text { The poem in itself is historical } \\
\text { (not written in the last decade) } \\
\text { and so needs to be read, as } \\
\text { in language class, within its } \\
\text { historical context. }\end{array}$ & $\begin{array}{l}\text { Either the content or the concept } \\
\text { of the poem link to CAPS content } \\
\text { e.g. - turning points in apartheid, } \\
\text { the exile struggle in the } 1980 \text { s, } \\
\text { slavery in South Africa, Trans- } \\
\text { Atlantic slave trade. Further than } \\
\text { this poems engage or exemplify } \\
\text { different historical arguments on } \\
\text { the topic. }\end{array}$ \\
\hline $\begin{array}{l}\text { Engage historical } \\
\text { thinking }\end{array}$ & $\begin{array}{l}\text { Each poem chosen offers } \\
\text { a particular perspective: } \\
\text { this engages historical } \\
\text { perspectives, and in some } \\
\text { poems presented as examples } \\
\text { in this article, multiple } \\
\text { perspectives are shown. } \\
\text { It is likely that other key } \\
\text { historical thinking skills such } \\
\text { as continuity and change, } \\
\text { cause and effect, and ethical } \\
\text { thinking will be engaged. } \\
\text { Each poem is also, in itself, a } \\
\text { piece of evidence, linking to } \\
\text { working with evidence. }\end{array}$ & $\begin{array}{l}\text { The CAPS document calls for the } \\
\text { following skills: } \\
\text { Engaging multiple perspectives. } \\
\text { Drawing information from } \\
\text { multiple sources. } \\
\text { Recognising that there are multiple } \\
\text { perspectives in history and } \\
\text { recognising why there are these } \\
\text { multiple perspectives. } \\
\text { Engaging the representations of } \\
\text { past in the present. }\end{array}$ \\
\hline Be compelling & $\begin{array}{l}\text { This is subjective and depends } \\
\text { on the teacher and the class. } \\
\text { It needs to be compelling } \\
\text { to the class, so one method } \\
\text { could be to ask students for } \\
\text { favourite poems or themes. If } \\
\text { the teacher finds it compelling } \\
\text { and the class does not, this in } \\
\text { itself could be a discussion } \\
\text { on historical perspective and } \\
\text { generation. }\end{array}$ & $\begin{array}{l}\text { Learners must understand why } \\
\text { there are different perspectives, } \\
\text { and be able to have focused and } \\
\text { constructive debate about the } \\
\text { issues that emerge in the poems, } \\
\text { substantiated by other historical } \\
\text { evidence. If the poems are not } \\
\text { compelling students will not be } \\
\text { motivated to debate. }\end{array}$ \\
\hline $\begin{array}{l}\text { Connect with relevant } \\
\text { items for students }\end{array}$ & $\begin{array}{l}\text { Linked to the above, this } \\
\text { speaks to who and where your } \\
\text { students are. The poem should } \\
\text { both speak to them, and open } \\
\text { up worlds for them to find } \\
\text { themselves in. }\end{array}$ & $\begin{array}{l}\text { This speaks to an interest in and } \\
\text { enjoyment of the study of the past. } \\
\text { This is easier if the sources used } \\
\text { are relevant. }\end{array}$ \\
\hline
\end{tabular}




\begin{tabular}{|l|l|l|}
\hline Writer positionality & $\begin{array}{l}\text { In terms of decolonisation, } \\
\text { and shifting the gaze, poems } \\
\text { that perpetuate a Eurocentric } \\
\text { view, where students cannot } \\
\text { find themselves or find } \\
\text { themselves belittled, are } \\
\text { not helpful. This is why the } \\
\text { explosion of particularly black } \\
\text { women writers in South Africa } \\
\text { makes poetry an interesting } \\
\text { methodology to explore right } \\
\text { now. }\end{array}$ & $\begin{array}{l}\text { Rather than a CAPS concept, this } \\
\text { speaks to a CAPS aim. Developing } \\
\text { an interest in and enjoyment of the } \\
\text { study of the past is one of the key } \\
\text { aims of history. This is more easily } \\
\text { realised if students see themselves } \\
\text { represented in some sources, or } \\
\text { some teaching aids brought into } \\
\text { the classroom. } \\
\text { Poetry provides potential for } \\
\text { centring previously marginalised } \\
\text { voices and narratives. }\end{array}$ \\
\hline $\begin{array}{l}\text { Connect with content } \\
\text { from CAPS }\end{array}$ & $\begin{array}{l}\text { For poems to be effective the } \\
\text { teacher and students must } \\
\text { be able to link them to the } \\
\text { content and skills in the CAPS } \\
\text { curriculum, as laid out in } \\
\text { column three. }\end{array}$ & $\begin{array}{l}\text { This addresses historical } \\
\text { knowledge called for in CAPS as } \\
\text { well as historical thinking skills. }\end{array}$ \\
\hline
\end{tabular}

\section{Decolonising the history curriculum: Poetry in pedagogy as process of decolonisation}

"We can't just wait for Black historians to rewrite these histories": a snippet, overheard in passing a group of students in a hall. I experienced a twinge: pain, guilt, surprise. This was perhaps because of the erasing the statement did - of the black historical canons, global, regional, national, to the current authors challenging the South African historiographical landscape. (I am thinking particularly of Professor Nomalanga Mkhize's \#BundyMustFall presentation at the SAHS conference in Stellenbosch a few years ago, drawn from her thesis (Mkhize, 2012).

But the point remained. The students do not see themselves in the historical literature we, as history education lecturers, are providing. In this section, I argue for poetry as a useful tool in decolonising historical thinking, historical theory, and historical pedagogy. I suggest poetry not as an intellectual replacement for the work of black historians as content engagement, but as a decolonising pedagogy towards the students seeing themselves, feeling themselves, more in the work we do in class. Below, I examine four poems that I have used in history methodology classes, and what potential historical content and thinking skills they open space for.

Koleka Putuma's "Water"- an award winning poem, now being taught in several English (but to my knowledge no history) courses at a tertiary level, speaks to the global condition of being black, but also to being women 
and being queer (Putuma, 2017). She, like Msimang, invokes history-inpresent, in different ways:

But I would rather exist in that god-less holy book than in the history books that did not tell truth

About us For us

On behalf of us

If you really had to write our stories

Then you ought to have done it in our mother's tongues The ones you cut off when you fed them a new language

We never consent

Yet we are asked to dine with the oppressors And Serve them forgiveness

How, when the only ingredients I have are grief and rage

Another one (who looks like me) died today

Another one (who looks like me) was murdered today

Putuma deals directly with the urgency that I feel pushes the need for decolonised theories of teaching history, and of historical thinking, when she writes "the only ingredients I have are grief and rage". When student teachers are only pushed to experience themselves as pedagogues and not as people the range of historical feeling is shut down, and ways that to unpack these feelings, and use them in historical teaching, on both skills, subject, and content, are shut down also. Putuma's emotion offered hand in hand with her history-in-present moment offers a powerful example of lived history as it is understood, felt, mourned, and raged against by the "I" of the poem.

"I expect more from you" by Vangile Gantsho presents a family's struggle history, primarily told through the women's experiences:

For you

my mother nursed, sold, sewed worked hard

when he couldn't work for us because he worked for you

As Lugones suggests, rather than adding an analytic category of gender into the implicit race, class and ideology in the poem, the gendering brings a lens of intensely experienced humanness. This introduction of subjective voice (layered with historical knowledge) in itself is a resistance to the coloniality of knowledge that classifies Black women as non-being (Lugones, 2010). It brings in a deep, personal, historically and subjectively informed rage and pain at the present political moment with the constant, building, refrain: "I expect more from you" (Gantsho, 2014:47). 
In terms of historical content, this poem does the work of looking at women's struggle histories, at different instantiations of the ANC in exile, at the transition moment or, moving to where we are now, either in the moment of 2014 when the poem was written, or in the current moment. It speaks to a range of CAPS curriculum subjects. It also allows for the feeling of the history-in- present that these lessons can also induce. Having the lesson framed around them facilitates a legitimacy of feeling, and so a legitimacy, or position of power, for the "I" in the poem.

Bringing these poems into class opens up avenues to discuss historical thinking, historical method, historical knowledge production, and historical narratives. It foregrounds emotions raised as these histories are taught. These poems present a worldview, links into historical content, the positionality, the immediacy, the history. They provide access points that are linked to different students through different modalities.

\section{Conclusion: Towards "a history in which I can see myself, in which I am not belittled",23}

There is much to be done towards decolonising the teaching of history in South Africa. The work is in the curriculum and in the classrooms, in the universities and in the minds of pre-service teachers, as well as the minds of the academics that teach them.

I have discussed poetry - not a new medium in teaching history, although usually either used as historical evidence or to teach empathy or cultural sensitivity (Furman, 2005; McCall, 2004) - as a tool that allows for a range of presence of subjectivities and thinking skills, including emotion, as well as more traditionally advocated historical thinking skills.

I have discussed the theories of historical thinking currently used in teaching history methodology, questioning how to decolonise this historical theory itself. Poetry is a method that works with perspective, voice, argument and evidence. Some students connect with poetry, and it can bring the historical narratives and complexities to life, as compelling creative work can do. Some students will hate poetry, and not connect with it, as with any specific teaching material. The argument I have made proposes poetry as one way towards a history and pedagogy that is more decolonised. Further research needs to do be done on how to decolonise the CAPS curriculum, in content and praxis, examining other media and

23 Moosa Khumalo, $4^{\text {th }}$ year Bachelor of Education student. Comment made in class and cited with permission. 
methods, as well as how our current curriculum is applied in all the diverse areas of our country. We need to pay attention to who is doing the research: what collection of students, teachers, and academics can best be brought together to draw on sufficient theoretical, experiential, and practical knowledge in an assemblage that takes on decolonisation. This research needs to be both long term and far reaching, to discover the potential, as well as where shifts have been, and are being, made.

In this paper I have taken guidance both from my students and from Wills' exploration of feminist decolonisation of the curriculum. This expands into decolonial thought on ways of resistance and being broader and how this can best be explored in history classrooms. The core of this ongoing project is guided by students I teach, decolonial, feminist and historical theory as well as education theory. It is guided by hope that decolonising the history classroom is possible and that this enables a more empowered and empowering history, in the history classroom in tertiary teacher education spaces as well as school classrooms.

Historical thinking presented as a skill set without considering the positionality and relationality of the student, and the knowledge interacted with, is dangerous. Teaching at the University of Johannesburg in 2016, I felt the strength of the emotions of a first-year class, as they argued that history is too painful, that all it does is encumber them with feelings they are not equipped to hold. In my work at Wits School of Education we have explored these feelings through poetry, as well as the fear these pre-service history teachers have about engaging or opening these feelings in learners. A project towards decolonising history needs to take these emotions into account. It needs to consider lived experiences, present day realities, and the shortcomings as well as successes while South Africa(ns) try to come to terms with history and present. Both local and global. We leave this incredibly challenging work to history teachers, sometimes without fully exploring the emotional challenges they face in classes. I propose poetry as one method to address this. Thus, true to the paper, I will end with a quote (that I use in all my classes, for when the teaching work gets hard for the students) from a poem by an American poet, Danez Smith:

Hope is hard, but I have it.

I look at my students' hands

Imagine all that they will mother

(Smith, 2016) 


\section{References}

Bam, J, Ntsebeza, L, Zinn, A 2018. Whose history counts: Decolonising African precolonial historiography, re-thinking African History. Bloemfontein, African Sun Media.

Bean, JC 2011. Engaging ideas: The professor's guide to integrating writing, critical thinking, and active learning in the classroom. New York, John Wiley \& Sons.

Booysen, S 2016. Fees must fall: Student revolt, decolonisation and governance in South Africa. Johannesburg, Wits University Press.

Crenshaw, K 1990. Mapping the margins: Intersectionality, identity politics, and violence against women of color. Stanford Review, 43:1241.

Department of Basic Education, 2011. Curriculum and assessment policy statement: Grades 4-6 Social Sciences.

Dominguez, CM 2012. Poetry is not a luxury: Queer poetry as a grassroots activist medium in South Africa. Unpublished MA Thesis, San Diego State University.

Dunbar-Ortiz 2015. An indigenous peoples' history of the United States. Beacon Press.

Elbow, P 2000. Everyone can write: Essays toward a hopeful theory of writing and teaching writing, 1. New York, Oxford University Press.

Freire, P 1996. Pedagogy of the oppressed. London, Penguin Group.

Furman, R 2005. Using poetry and written exercises to teach empathy. Journal of Poetry. Therapy, 18:103-110.

Gennrich, T, Dison, L 2018. Voice matters: Students' struggle to find voice. Reading and Writing, 9:8.

Gordon, LR 2011. Shifting the geography of reason in an age of disciplinary decadence. TRANSMODERNITY Journal of Peripheral Cultural Production in the Luso-Hispanic World, 1.

Gqola, PD, 2011. Whirling worlds? Women's poetry, feminist imagination and contemporary South African publics. Scrutiny, 2(16):5-11.

Hlalethwa, Z 2019 Books that heal and save lives. Mail and Guardian Available at. https://mg.co.za/article/2018-06-15-00-books-that-heal-and-save-lives/. Accessed 9 June 2019. 
Hooks, Bell 1994. Teaching to transgress: Education as the practice of freedom. New York, Routledge.

Kelly, LL 2013. Hip-Hop literature: The politics, poetics, and power of Hip-Hop in the English classroom. The English Journal, 102:51-56.

Kim, RH 2013. Never knew literacy could get at my soul: On how words matter for youth, or notes toward decolonizing literacy. Review of Education, Pedagogy and Cultural Studies, 35:392-407.

Koleka Putuma: Providing a poetic cure for society's collective amnesia, 10 and 5, 2017. Available at https://10and5.com/2017/04/18/koleka-putuma-providing-apoetic-cure-for-societys-collective-amnesia/. Accessed on 9 June 2019.

Lugones, M 2010. Toward a decolonial feminism. Hypatia 25:742-759.

Maldonado-Torres, N 2016. Outline of ten theses on coloniality and decoloniality. Franz Fanon Foundation, 37.

McCall, AL 2004. Using poetry in social studies classes to teach about cultural diversity and social justice. Social Studies, 95:172-176.

Mgqwetho, N 2007. The nation's bounty: The Xhosa poetry of Nontsizi Mgqwetho. Johannesburg, Wits University Press.

Monte-Sano, C 2012. What makes a good History essay? Assessing historical aspects of argumentative writing. Social Education, 76:294-298.

Morton, T, Seixas, P 2012. The big six historical thinking concepts, 1. Toronto, Nelson Canada.

Mqhayi, SEK 2017. Iziganeko zesizwe: Occasional poems (1900-1943). Durban, University of KwaZulu-Natal Press.

Ndlovu, SM, Lekgoathi, S, Esterhuysen, A, Mkhize, NN, Weddon, G, Callinicos, L, Sithole, J 2018. Report of the History Ministerial Task Team for the Department of Basic Education. Department of Basic Education, Pretoria, South Africa.

Ngcaweni, W, Ngcaweni, B (Eds.) 2018. We are no longer at ease: The struggle for fees must fall. South Africa, Johannesburg, Jacana Media.

Olaowula, SS 2016. Facing up to the horror: Of passion, multiple complicity and survival, in Manu Herbstein's AMA: A story of the Atlantic slave trade. In: S Dixon, J Spleth (Eds.), Cultural Dynamics of Globalisation and African Literature. New Jersey, Africa World Press. 
Ortiz, P 2018. An African American and Latinx History of the United States. Boston, Beacon Press.

Patel, S 2010. Migritude. University of Southern California, Kaya Press.

Putuma, K 2017. Collective Amnesia. Cape Town, South Africa, uHlanga,.

Shalem, Y, Dison, L, Gennrich, T, Nkambule, T 2013. 'I don't understand everything here ... I'm scared' : Discontinuities as experienced by first-year education students in their encounters with assessment. South African Journal of Higher Education, 27:1081-1098.

Solnit, R 2005. Hope in the dark: Untold histories, wild possibilities. New York : Berkeley, California, Nation Books.

Tambyah, M 2017. Teaching for 'Historical understanding': What knowledge(s) do teachers need to teach History? Australian Journal of Teacher Education, 42.

Teeger, C 2015. "Both sides of the story": History education in post-apartheid South Africa. American Sociological Review, 80:1175-1200.

Trouillot, M-R 1997. Silencing the past: Power and the production of History. Boston, Beacon Press.

Wills, L 2016. The South African high school history curriculum and the politics of gendering decolonisation and decolonising gender. Yesterday \& Today:22-39.

Wineburg, S 2001. Historical thinking and other unnatural acts: Charting the future of teaching the past. Philadelphia, Temple University Press.

Xaba, M 2008. Tongues of their mothers. Scottsville, South Africa, University Of KwaZulu-Natal Press.

Zinn, H 2005. A people's history of the United States. New York, Harper Perennial Modern Classics. 